\title{
“QUEM DOUTRINE E ENSINE OS FILHOS DAQUELES MORADORES": A COMPANHIA DE JESUS, SEUS COLÉGIOS E O ENSINO NA AMAZÔNIA COLONIAL ${ }^{1}$
}

\author{
Rafael Chambouleyron \\ Universidade Federal do Pará (UFPA) \\ Karl Heinz Arenz \\ Universidade Federal do Pará (UFPA) \\ Raimundo Moreira das Neves Neto \\ Universidade Federal do Pará (UFPA)
}

\section{RESUMO}

Falar de ensino jesuítico, não significa somente pensar o ensino da doutrina e das escolas nas aldeias de índios livres, espaços privilegiados da missão jesuítica na América portuguesa, desde meados do século XVI. Igualmente fundamental foi a reflexão sobre o ensino dos filhos dos moradores e os primeiros intentos de formar noviços da terra. Esta experiência, por outro lado, deve ser pensada para além da mera questão do ensino, pois significava também refletir sobre as formas de inserção da Ordem no mundo português que se criava com a ocupação da Amazônia; os colégios que a Companhia fundou nas cidades de Belém e São Luís ganham aí um papel central. O objetivo deste artigo é o de compreender a relação das atividades de ensino dos padres jesuítas na Amazônia colonial com as formas políticas e econômicas por meio das quais se articularam na região.

Palavras-Chave: Companhia de Jesus; Amazônia; Ensino; Séculos XVII e XVIII

\section{"WHO INDOCTRINATES AND TEACHES THE SONS OF THE SETTLERS": THE SOCIETY OF JESUS, ITS COLLEGES AND EDUCATION IN THE COLONIAL AMAZON REGION}

\begin{abstract}
Jesuit teaching in Portuguese America cannot be understood only from the viewpoint of the educational activities undertaken by the priests in the American Indian villages as the privileged place of their apostolate. As important as these actions was the indoctrination and teaching of the Portuguese settlers' sons and the first attempts to form a native clergy. Both the Jesuits' activities with the Indians and with the Portuguese had to be understood beyond the educational approach, since they were supported by the many ways the Order established itself in the colonial society, especially founding two colleges in the region. This article aims to understand the relationship between teaching and the political and economic grounds of the Society of Jesus in the Portuguese Amazon region.

Keywords: Society of Jesus; Portuguese Amazon region; Education; Seventeenth and Eighteenth centuries
\end{abstract}


Os jesuítas se instalaram no Estado do Maranhão e Pará - região que corresponde aproximadamente à atual Amazônia brasileira - desde a década de 1650, com a chegada do famoso padre Antônio Vieira. ${ }^{2}$ Embora tivessem estado na região em ocasiões anteriores, é somente em 1653 que, de fato, podemos falar de uma presença sistemática e definitiva da Companhia - não sem importantes transformações e reordenamentos (ARENZ, 2010, p. 70-72) -, até a sua expulsão no final da década de 1750 e início dos anos 1760.

No Estado do Maranhão e Pará, durante o século XVII, os religiosos construíram uma rede de colégios (Santo Alexandre, em Belém; e Nossa Senhora da Luz, em São Luís) aldeias e residências (nessas aldeias) que consolidou o seu poder e seu apostolado na região. O crescimento da ordem, principalmente no século XVIII, ensejou inúmeros conflitos com moradores e autoridades, sobretudo em torno do controle sobre a aquisição e uso da mão-de-obra indígena, fundamental na região (AZEVEDO, 1930; LEITE, 1943b; REIS, 1950; KIEMEN, 1954; HAUBERT, 1964; ALDEN, 1969; MACLACHLAN, 1973; SWEET, 1974; GROSS, 1975; SWEET, 1981; BELLOTO, 1982; ALDEN, 1984; ALDEN, 1985; ALMEIDA, 1988; FARAGE, 1991; SARAIVA, 1992; PERRONE-MOISÉS, 1993; PORRO, 1996; MONTEIRO, 1992a; MONTEIRO, 1992b; OLIVEIRA, 2001; SOUSA, 2002; COELHO, 2005; SOMMER, 2005; MELLO, 2005; CARVALHO JÚNIOR, 2005; LIMA, 2006; GUZMÁN, 2006; MELLO, 2006; GUZMÁN, 2008; DIAS, 2009; SOUZA JR, 2009; MELLO, 2009b, p. 243-317; ARENZ, 2010). A historiografia tem insistido nesse embate como uma perspectiva interpretativa para entender a própria presença jesuítica na Amazônia, o que ensejou que se deixassem de lado outros aspectos importantes do apostolado da Companhia de Jesus, que são igualmente relevantes para entender a forma como a Ordem organizou o seu governo na região.

É nesse sentido que se pode refletir sobre as atividades educativas da Companhia de Jesus na Amazônia. O ensino jesuítico é conhecido desde o princípio da Ordem, quando, como define um biógrafo de Santo Inácio, a Companhia de Jesus, inicialmente missionária, pouco a pouco se transformou numa "Ordem docente" (GARCÍA-VILLOSLADA, 1991, p. 833). Pouco depois de sua fundação, a Companhia de Jesus orientou seus objetivos não somente para a instrução de seus próprios membros, mas também dos jovens em geral. Desta maneira, como explica Josette La Roche, os jesuítas buscaram "ensinar as letras e a virtude à juventude, com o objetivo de fazê-la um meio de promoção dos valores defendidos pela Companhia, em seu mundo" (LA ROCHE, 1996, p. 194). Nesse sentido, na América portuguesa, falar de ensino, não significa somente pensar o ensino da doutrina e das escolas nas aldeias de índios livres, espaços privilegiados da missão jesuítica na América portuguesa, desde meados do século XVI. Igualmente fundamental foi a reflexão sobre o ensino dos filhos dos moradores e os primeiros intentos de formar noviços da terra. Esta experiência, por outro lado, deve ser pensada para além da mera questão do ensino, pois significava também refletir sobre as formas de inserção da Ordem no mundo português que se criava com a ocupação da Amazônia; os colégios que a Companhia fundou nas cidades de Belém e São Luís ganham aí um papel central.

De fato, se o ensino dos meninos índios e dos catecúmenos era uma preocupação fundamental da Companhia de Jesus no Maranhão e Pará (ARENZ, 2010, p. 485-488), como o fora e era então também em todo o Brasil, a chegada do padre Vieira a São Luís, implicou igualmente uma articulação que ia além do problema da evangelização dos índios. Se havia que formar os índios aldeados, havia igualmente que instruir os moradores das comunidades portuguesas, principalmente das cidades de São Luís e Belém. ${ }^{3}$

O papel dos padres como pastores da população portuguesa assumiu um lugar muito importante no apostolado dos religiosos no Estado do Maranhão e Pará e, como dissemos, foi freqüentemente relegado a um segundo plano pela historiografia. Vale a pena 
retomar alguns aspectos da missão entre os moradores, e de que maneira o ensino se torna algo fundamental para o próprio lugar da missão jesuítica na Amazônia colonial. Significativamente, em carta ao provincial do Brasil, escrita provavelmente em 1654, o próprio padre Vieira enfatizava que com os portugueses "se não tem trabalhado menos que com os índios". Em seguida, detalhava os ministérios levados a cabo pelos religiosos.

nos sermões dentro e fora de casa; nas doutrinas de todos os dias; no exemplo da Senhora e práticas aos sábados; nos jubileus e festas principais; na visita de presos e enfermos; na devoção e ensino dos estudantes, assim no estudo de latim como na escola de ler e escrever; e geralmente nos ministérios próprios de nosso instituto nunca se tem faltado, sem embargo de sermos tão poucos, e carregar muitas vezes grande parte destas ocupações sobre um só até dois (VIEIRA, 1997c [1654], p. 389).

Relatando a chegada do padre Vieira ao Maranhão, o padre Bettendorff conta que "passados os primeiros dias de descanso e visitas", o padre Vieira, como superior da missão, procurou "pôr correntes todas as funções da Companhia". Em primeiro lugar, instituir o terço, que todos os dias depois da classe, às cinco horas, era cantado "pelos estudantes da escola diante da imagem de Nossa Senhora da Luz"; não querendo que esta devoção terminasse, o padre Vieira ainda estabeleceu uma "confraria com seu compromisso" de cujas celebrações participavam os "músicos de Nossa Senhora das Mercês". Entre outras disposições, o padre Vieira ordenou aos seus "súditos" como se dizia à época, que nos domingos e festas andasse um padre, "com a cana na mão", que, acompanhado dos "estudantes com a sua bandeira" juntos cantassem as "orações e ladainhas" pela cidade. Além disso, o superior determinou que "se visitassem as prisões e hospital, ou casa da Misericórdia e mais aos doentes, para que não faltássemos a nenhuma obra de caridade". Finalmente, antes de passar a relatar o apostolado com os índios, o padre Bettendorff conta que o padre Vieira determinara que "houvesse sepulcro com o Senhor exposto e pregação" (BETTENDORFF, 1990 [1698], p. 78).

Como religiosos, os jesuítas administravam os sacramentos aos habitantes das vilas e cidades do Estado do Maranhão, principalmente São Luís e Belém. Não há dúvida que o mais importante dos sacramentos era a confissão. ${ }^{4}$ De fato, a confissão representava um momento fundamental no qual não somente se confessavam os pecados, mas também quando se discutiam problemas importantes, como o da escravização ilegal dos índios. Antes de embarcar para o Maranhão, o padre Vieira escrevia ao provincial do Brasil, explicando que haviam resolvido "a não falar em índios mais que no confessionário, quando o peça o remédio de suas consciências e a satisfação das nossas" (VIEIRA, 1997a [1652], p. 278). Pouco tempo depois de chegar a São Luís, novamente se correspondia com o provincial. Na carta deixava claro que a confissão era um momento importante para falar com os senhores de escravos de "tudo o que convém para bem de suas almas, e também tudo o que for a bem dos índios, para que não cativem injustamente os livres, nem tratem mais rigorosamente do que convém aos escravos" (VIEIRA, 1997c [1654], p. 389).

Mas as confissões eram também um momento em que também se podia reforçar a própria influência política da Companhia. Para João Francisco Marques, desde o século XVI, em Portugal, os jesuítas assumiram um importante papel como confessores de reis, príncipes e nobres influentes, adquirindo, desta maneira, ascendência política e religiosa nos negócios do reino. ${ }^{5}$ No Maranhão, alguns padres foram confessores de governadores, como o padre José Soares, com o qual o governador Dom Pedro de Melo normalmente "se 
confessava" (VIEIRA, 1940c [1661], p. 284). Anos mais tarde, em 1667, segundo relata o padre João Felipe Bettendorff, depois de chegar de Lisboa, o novo governador, Antônio de Albuquerque Coelho de Carvalho, foi até o colégio dos jesuítas, ofereceu esmolas, confessou-se com ele e continuou se confessando "enquanto esteve no Estado" (BETTENDORFF, 1990, p. 245). Além de ouvirem, com preferência, as confissões dos homens notáveis da colônia, os inacianos contaram com uma afluência significativa das senhoras brancas. Esta prática constituiu um meio tanto de manter-se informado quanto de poder influenciar - mediante as esposas - os principais administradores do Estado. Uma outra "especialidade" dos jesuítas foi a chamada confissão geral que consiste em uma revisão minuciosa de toda a vida, sendo praticada com frequência durante a quaresma. Adeptos do casuísmo e formados dentro da visão da "teologia da graça", os inacianos tenderam geralmente a mostrar-se mais compreensivos para com os penitentes do que outros confessores; fato que explica sua popularidade nos confessionários (BETTENDORFF, 1671b, fl. 261v e 266v).

Em 1681, o primeiro bispo do Maranhão, Dom Gregório dos Anjos, recusou-se a conferir a certos jesuítas a autorização para ouvirem confissões, mesmo nas aldeias sob os cuidados pastorais da Companhia. De fato, o prelado recém-chegado (1679) pretendia desafiar os inacianos para que colaborassem mais estreitamente com ele enquanto autoridade eclesiástica máxima da colônia. Sem dúvida, a querela que revela a incompatibilidade entre o fortalecimento proposital da autoridade episcopal pela Coroa - conforme as orientações do Concílio de Trento - e a costumeira autonomia dos jesuítas em assuntos espirituais, possuiu uma clara conotação política, pois teve impactos imediatos nas relações entre os principais agentes sociais da colônia; conotação essa que não escapou à análise do padre Bettendorff (1990, p. 338; 1681, fl. 146-147). Além disso, numa época que viu o sacramento da confissão como um meio essencial para a evangelização, a medida drástica do prelado equivalia a uma afronta sem igual contra os missionários. É uma carta do padre Vieira que sugeriu finalmente uma solução. O padre português recomendou que seus irmãos de batina cedessem ao bispo no que diz respeito aos lugares de culto e às rubricas litúrgicas, mas que não permitissem interferência nenhuma na administração espiritual das missões, sob a alegação de se tratar de um direito garantido pelo rei (VIEIRA, 1680 [1971], p. 442-444).

Durante as missas, o sermão era igualmente um momento significativo, principalmente entre 1653 e 1661, quando esteve no Maranhão o pregador mais importante da língua portuguesa do século XVII, o padre Antônio Vieira. Como já destacou Beatriz Catão, a pregação era um "dos instrumentos pelos quais o padre Antônio Vieira intervinha na política colonial, lato sensu, da região" (SANTOS, 1997, p. 94).

O padre Vieira não foi o único pregador do Maranhão, embora sua fama exceda (e com razão) a dos demais jesuítas da missão. Em sua Crônica, o padre Bettendorff refere-se em vários momentos a outros pregadores, como ele mesmo, em 1670, quando fez um sermão por ocasião da festa de São Francisco Xavier, patrono da igreja do Pará, "sendo o auditório muito grande, pelo concurso de gente a essa novidade" (BETTENDORF, 1990, p. 255). Na carta ânua de 1671, ele descreve com mais ênfase ainda os supostos impactos de "práticas" (pregações) e "meditações" (reflexões de cunho moral que pretendem induzir o ouvinte a rever a sua conduta) sobre a população branca. Para dar mais força às palavras, os jesuítas recorriam à rica produção pictórica e escultórica do barroco, exibindo, conforme a época litúrgica, estátuas impactantes como presépios (em Gurupi) ou cenas da paixão de Cristo (em São Luís). Vê-se que a "pedagogia visual" não se restringia somente à 
evangelização dos índios, sendo que o uso de imagens para impressionar e intimidar foi muito frequente nos aldeamentos (BETTENDORFF, 1671b, fl. 261v, 264 e 266v). Nem só portugueses ou europeus de uma forma geral, eram os que faziam os sermões. O padre Antônio Pereira era "natural do Maranhão" e "pregador no colégio do Maranhão". Ele havia estudado no Brasil, de lá vindo "já professo de quatro votos" (BETTENDORF, 1990, p. 388,324$)$.

Ao lado dos sacramentos, os jesuítas organizavam devoções e irmandades, além de se devotarem à caridade. Apenas chegou a São Luís do Maranhão, o padre Vieira organizou, por exemplo, a devoção de Nossa Senhora, invocação "desta igreja" (Nossa Senhora da Luz). ${ }^{6}$ Os cantos começavam ao entardecer, e a eles compareciam "todos os estudantes e meninos da nossa escola". Mas também participavam da devoção "muitos soldados e gente de todos os estados". De acordo com o padre Vieira, a devoção durava cerca de uma hora e aos sábados o auditório enchia-se de gente. Escrevendo ao provincial do Brasil, explicava que seguramente muitos pensavam que "este modo de devoção com canto público" não era próprio da Companhia de Jesus. Entretanto, assegurava ao provincial que devoções similares se faziam na casa professa de Roma, e além do mais, quê melhor meio que atrair almas a Deus que por "uma tão segura e aprovada [maneira] como a devoção da Virgem, a maior das suas devoções" (VIEIRA, 1997b [1653], p. 337$338)$.

No ano de 1670, o padre Bettendorff, muito empenhado na promoção da pastoral entre os moradores, redigiu os estatutos para uma confraria mariana em São Luís. O fato de ele ter conseguido a aprovação dos mesmos pelo superior geral revela a importância que se atribuiu ao reconhecimento formal e oficial destes leigos associados à Companhia de Jesus (BETTENDORFF, 1670, fl. 2-8; ARENZ, 2010, p. 292 e 490). Da mesma forma, a concessão frequente do título de "amigo" ou "irmão da Companhia" a benfeitores geralmente civis abastados e administradores ou militares influentes - aponta o interesse de atrelar pessoas de destaque na colônia ao projeto jesuítico (ARENZ, 2010, p. 346 e 463).

De fato, para além de sua clara função religiosa, muitas atividades dos jesuítas entre os portugueses constituíam uma forma de reforçar sua posição política na região. Em uma carta ao geral da Companhia, o padre Goswin Nickel, o padre Vieira comentava sobre os perigos das relações estabelecidas entre religiosos e leigos, mas ao mesmo tempo também expressava a urgente necessidade de estabelecer alianças com os moradores portugueses e com as autoridades do Estado. Como apontou Fernando Torres-Londoño, "a dedicação à salvação das almas entendida pelos missionários à luz de seu carisma [inaciano]", se traduziu em duas dimensões presentes nos textos escritos pelos jesuítas do Maranhão, o governo espiritual e o governo temporal. De acordo com Torres-Londoño, fiéis ao "estilo inaciano, que valorizava o político como expressão fundamental da ação", os religiosos não separaram estas duas dimensões, fazendo uma só, como mecanismo para conseguir a salvação das almas (TORRES-LONDOÑO, 1999, p. 23). Dessa maneira, na carta ao geral, o padre Vieira escrevia que "com os seculares se trata e se contemporiza somente quanto é necessário para promover o fim da missão, que como tão encontrada dos interesses humanos, tem grandes dependências dos homens" (VIEIRA, 1940c [1661], p. 285).

No século XIX, essa frase provavelmente seria lida como uma prova da alegada "racionalidade" dos jesuítas, para os quais os fins importavam mais que os meios. Entretanto, o que ela indica é que os padres tinham que operar num contexto de constante conflito entre diferentes grupos, alguns dos quais estavam radicalmente opostos aos 
interesses da Companhia. Os religiosos, portanto, tinham que estar intimamente comprometidos com atividades que os ajudassem a consolidar seus interesses e pontos de vista sobre a missão e sobre a própria maneira como era governado o Estado do Maranhão. Isso significava igualmente refletir sobre os limites da ingerência dos padres no mundo secular. O ensino assumiu aí um papel central.

No século XVII, na América portuguesa, os jesuítas tinham dois colégios, Nossa Senhora da Luz (em São Luís) e Santo Alexandre (em Belém). Fundadas, respectivamente, em 1622 e 1652, estas primeiras residências urbanas foram elevadas à categoria de colégio em 1670 - recebendo seus superiores a patente de reitor (BETTENDORFF, 1671b, fl. 266v). Em 1702, nas palavras de Antônio Baena, fundaram os padres na Vigia "uma igreja ampla e um colégio para instrução da mocidade, e nele formaram um grande número de clérigos" (BAENA, 1839, p. 338). Pelo que se pode entender das cartas e relações dos jesuítas do Maranhão e Pará, durante o século XVII, as atividades educativas não foram tão produtivas como em outros lugares, como, por exemplo, o colégio da Bahia. Talvez o reduzido número de religiosos e a extensão do território sobre sua responsabilidade fizessem seu trabalho improdutivo e mais difícil. Um dos religiosos que havia chegado ao Maranhão com o padre Vieira, em 1653, chegara a contar ao padre Bettendorff que "às vezes por falta de quem ficasse em casa fechavam as portas, e se iam para as aldeias mais vizinhas para acudir a suas missões", o que acontecia tanto no Pará como no Maranhão (BETTENDORFF, 1990, p. 89).

De qualquer modo, as escolas abertas aos filhos dos portugueses funcionaram com maior regularidade a partir de 1653, muito embora, esclarece o padre Serafim Leite, não tenham tido "existência ininterrupta"; tendo inclusive ocorrido aulas de latim em períodos anteriores, por ocasião das várias tentativas de instalação da missão, durante a primeira metade do século XVII. Tudo indica que as primeiras classes de latim para os filhos de colonos foram abertas, em 1626, pelo padre Luís Figueira (LEITE, 1943b, p. 262-263). Em 1653, o padre Vieira informava ao provincial do Brasil que mais de setenta "estudantes e meninos da nossa escola" iam à doutrina, "e o fazem com gosto e sujeição, algo que é coisa que nos admira naquela idade". Para o padre Vieira, ensinar os meninos dos portugueses significava abrir a porta para que alguns deles entrassem na Companhia, o que seria muito útil, "porque quase todos sabem a língua da terra". Nessa mesma carta, o padre Vieira já expressava seu desejo de que alguns deles entrassem na Companhia (VIEIRA, 1997b [1653], p. 340). No final dos anos 1660, os avanços com as crianças animaram o padre Bettendorff a abrir uma "classe de latim" em Belém, juntando os estudantes da escola, entre eles "dois filhos senhor do governador". Entretanto, apesar de os meninos já estarem traduzindo Quinto Curcio, a Câmara de Belém não quis dispensar os jovens de "assentar praça". O religioso teve que fechar a classe e não houve mais latim até 1695 (BETTENDORFF, 1990, p. 280). Mesmo assim, parece ter havido nesse intervalo classes de alfabetização ministradas por coadjutores temporais. O padre Bettendorff destaca, sobretudo, os talentos de mestre dos irmãos Baltasar do Campo (holandês) e Marcos Vieira (português). Os habitantes de Belém reclamaram, em 1688 e 1689, que os jesuítas não haviam começado ainda com o ensino do latim, apesar de uma ordem expressa da Coroa. A situação melhorou com a chegada de novos missionários na virada da década de 1690 . Entre estes se encontraram também pedagogos talentosos como o coadjutor temporal Tomás de Couto, "o qual tinha ensinado uns anos a classe de latim no Maranhão, com muita satisfação dos de dentro e de fora", ao ponto de surpreender a cidade com apresentações de peças teatrais e declamações de poemas e orações dos alunos (BETTENDORFF, 1990, p. 532; ARENZ, 2010, p. 430). 
Os problemas e dificuldades das escolas no Pará e no Maranhão pareciam bastante claros. Em 1661, um dos mais acerbos opositores da Companhia no Estado do Maranhão e Pará, Jorge de Sampaio e Carvalho, procurador do Estado, acusara os padres de que tendo o rei concedido aos padres

$30 \$ 000$ réis a cada um com obrigação de terem escolas de ler e escrever e ensinarem gramática e artes e doutrinarem os índios e portugueses [...] posto que no princípio começaram com algum fervor, pelo tempo em diante faltaram a sua obrigação e só de suas conveniências trataram (CARVALHO, 1921 [1661], p. 12).

Respondendo às acusações formuladas pelo procurador, o padre Vieira defendia-se lembrando que na capitania do Maranhão havia classe de latim "por mera caridade e sem obrigação alguma"; mais ainda, em razão da pobreza dos alunos, escrevia que "porque os estudantes não tinham artes, nem cartapácios, nem livros, os padres lhos davam de graça, e a alguns até o papel, tinteiros e as penas". No Pará, a situação era mais grave, pois abrindose duas escolas, "porque faltaram os discípulos, não continuaram os mestres". Mesmo assim, lembrava o padre Vieira, os religiosos do Carmo e das Mercês haviam aprendido "o latim que sabem", nas escolas da Companhia (VIEIRA, 1951 [1662], p. 210). ${ }^{7}$

Os estudos de Filosofia, Teologia e Teologia Moral se consolidariam lentamente no século XVIII, tanto em São Luís como em Belém (LEITE, 1943b, p. 263-265 e 273-275). De fato, nas décadas de 1660 a 1690, a Missão dispôs de um tipo de curso complementar em teologia moral, destinado aos padres jovens que, tendo o status de coadjutores espirituais, ainda não eram professos dos quatro votos. As aulas e os lugares foram definidos ad hoc conforme a demanda e as condições do docente. No primeiro quinquênio dos anos 1660, o padre Manuel Nunes, já idoso, estava "ensinando nestas partes [em São Luís] a filosofia e partes de teologia". Já em 1665, a teologia moral foi assumida pelo padre Bettendorff, reitor, que dizia só ensinar "aquilo que os teólogos ensinam". Na mesma época, o padre Antônio Soares deu as humaniora, isto é, as humanidades. Em 1671, o padre Bettendorff lamentou que "por falta de mestres, têm que se ensinar classes triviais [básicas] ao invés das humanidades", atribuindo a irregularidade das aulas também ao fato de o governador não liberar "os nossos estudantes" do serviço militar. No mesmo ano, o curso de teologia moral estava acontecendo em Gurupi, sendo o padre Salvador do Vale, muito enfermo, o responsável. O padre Bettendorff admite implicitamente o caráter medíocre destes estudos teológicos complementares e elementares (BETTENDORFF, 1665, fl. 12-12v; 1671a, fl. $2 \mathrm{v} ; 1671 \mathrm{~b}, \mathrm{fl} .261 \mathrm{v}$ e $264 \mathrm{r}$ ).

Três tentativas sucessivas, lançadas ao longo da década de 1670, não conseguiram dar um caráter mais regular aos estudos filosóficos e teológicos. Naqueles anos, aumentaram as missivas enviadas à cúria central da Companhia apontando para a necessidade de um ensino de maior qualidade, sobretudo no que concernia às disciplinas de latim e filosofia. Escreveram tanto missionários "veteranos", como o padre italiano João Maria Gorzoni, quanto novatos, como o padre suíço Jódoco Perret - ele mesmo destinado ao ensino da filosofia (ARENZ, 2010, p. 432-433). Um passo importante foi dado com a abertura do noviciado, em 1676, com dois - a partir de fevereiro de 1677, quatro - noviços, sendo o padre Antônio Pereira o primeiro mestre (BETTENDORFF, 1678, fl. 45; 1990, p. 312 e 316). Em 1679, o padre italiano Estêvão Gandolfi, missionário recém-chegado, foi nomeado novo mestre de noviços, sendo que, naquele ano, o grupo dos formandos se compôs de sete noviços e "alguns" estudantes de filosofia e teologia, dos quais alguns enviados da Província do Brasil (BETTENDORF, 1679, fl. 62-62v). Porém, devido à 
precariedade dos meios de sustento e à irregularidade das aulas, o superior geral mandou fechar os cursos abertos em 1679 (LEITE, 1943b, p. 234-235). Mesmo assim, em 1679, o padre Perret, novato na Missão, propõe com insistência a fundação de um seminário reservados para candidatos indígenas (PERRET, 1679, fl. 61). Já o padre João Maria Gorzoni, mais experiente, sugere três anos mais tarde, ao menos a implantação da etapa básica, a das humanidades consistindo em aulas de latim e filosofia elementar (GORZONI, 1682, fl. 95-95v).

Somente nos anos que seguiram o levante de 1684 e a introdução do Regimento das Missões trouxeram certa estabilidade. ${ }^{8}$ Assim, a vinda de padres com uma formação acadêmica - José Ferreira, Inácio Ferreira e Manuel Galvão - entre 1688 e 1690, fez do colégio de São Luís um lugar onde se ensinava, finalmente, todas as etapas da formação jesuítica (BETTENDORFF, 1990, p. 532; ARENZ, 2010, p. 431-434). A consolidação se evidencia com o término solene dos primeiros cursos inteiramente realizados na Missão, a saber: a teologia em São Luís, em 1692; a filosofia em Belém, em 1696; e as humanidades em Belém, em 1697 (BETTENDORFF, 1990, p. 507, 612-613 e 659-660). Com respeito ao cume da formação clerical, a ordenação presbiteral, o padre Bettendorff anota com satisfação que, em 1697, o "Senhor Bispo D. Timóteo do Sacramento ordenou todos os nossos teólogos que há de presente na Missão, capacitando-os com isso para as missões, pelas quais se repartitão" (BETTENDORFF, 1990, p. 674). Destarte, a introdução definitiva de todas as etapas da formação jesuítica na Missão do Maranhão alastrou-se durante vinte anos: de 1676 (abertura do noviciado permanente) até 1697 (ano das primeiras ordenações sacerdotais), passando pelas diferentes tentativas de instaurar os estudos humanísticos, filosóficos e teológicos (ARENZ, 2010, p. 435).

O ensino ministrado pelos jesuítas era já conhecido dos portugueses na América, pelo menos desde meados do século XVI. Apesar do tom aparentemente laudatório, é precisa a afirmação do padre Bettendorff, em sua Crônica, ao afirmar que, ao chegarem os primeiros padres ao Maranhão, em 1652, "foram muito bem aceitos dos moradores desejosos de terem consigo os padres da Companhia de Jesus, assim para seu bem espiritual, como para ensinança dos seus filhos e escravos e índios das aldeias" (BETTENDORFF, 1990, p. 75).

Os já sabidos problemas que confrontavam os moradores aos religiosos, em torno do problema da mão-de-obra indígena, não significava que os portugueses não vissem nos padres uma excelente oportunidade para que seus filhos pudessem estudar no Estado do Maranhão. Como discute David Brading, no México colonial, por exemplo, a chegada dos padres jesuítas foi saudada pela elite criolla uma vez que representava a possibilidade de educação para seus filhos (BRADING, 2001, p. 59). Apesar do tom apologético de seu livro, o padre José Coelho de Souza tem razão quando lembra que "aqui no norte, meio mais restrito, assinalaram também sua passagem nos meios culturais, quer muitos jesuítas, quer muitos dos seus ex-alunos, que saídos dos bancos escolares subiram aos mais altos cargos do sacerdócio, da magistratura e da milícia" (SOUZA, 1977, p. 77). Nesse sentido, o ensino ministrado pelos padres na Amazônia colonial tinha igualmente um sentido político muito claro. Esse sentido político se tornava ainda mais evidente quando o padre Vieira discutia com as autoridades da Companhia um desejo expressado em várias ocasiões, o da formação de um clero maranhense.

Algumas cartas do padre Vieira às autoridades da Companhia de Jesus revelam o quanto este religioso estava empenhado em fundar e organizar um noviciado no Maranhão. 
A questão do noviciado, como mostra o padre Serafim Leite, sempre fora um tema polêmico, que ensejara inúmeras opiniões tanto na Missão do Maranhão, com em Lisboa e Roma. A solução final para esta questão nunca chegara a se concretizar, o que poderia ter ocorrido com a elevação do Maranhão a Província, que se dera em 1759, quando da expulsão dos padres da região (LEITE, 1943b, p. 233-237; ARENZ, 2010, p. 427-428).

Para o padre Vieira, com o crescimento da missão, a instituição do noviciado constituía uma ferramenta importante para consolidar os interesses da Companhia. Ao provincial do Brasil, o religioso escrevia, em 1660,

cresce este corpo cada dia mais, e cada dia promete novos aumentos. No Maranhão ficamos trabalhando em um colégio, que venha a ser de criação, em que haja noviciado e estudo, suposto necessitar a missão de tantos sujeitos, e os mais que vêm não trazerem os estudos acabados, nem poderem ir acabá-los a outra parte" (VIEIRA, 1997d [1660], p. 753).

Segundo o padre Vieira, por um lado, os noviços recebidos no Maranhão estavam melhor adaptados ou se adaptariam facilmente às condições da terra. Isso significava, como escrevia ao geral da Companhia em 1661, que os jovens recebidos para estudar no Maranhão "se acomodam ao clima, aos mantimentos e aos costumes da terra, aprendem e tomam as línguas com grande facilidade e as pronunciam com toda perfeição" (VIEIRA, 1940c [1661], p. 292). Em 1677, dezesseis anos depois de deixar o Maranhão, o padre Vieira escrevia ao superior da missão, padre Pier Luigi Consalvi, insistindo que a juventude do Maranhão era "natural do clima". Se a adaptação era uma vantagem, emendava o religioso, receber noviços no Maranhão também seria mais barato, porque a Companhia não teria que gastar em trazer religiosos de "terras tão remotas" (VIEIRA, 1947b [1677], p. 467).

Por outro lado, o noviciado do Maranhão teria um papel estratégico. De fato, já em 1656, o padre Vieira explicava ao provincial do Brasil que, dentre outras razões, abrir o noviciado significaria não somente receber "muito bons sujeitos filhos da melhor gente desta terra", senão também que o estudo seria um "meio, e o mais eficaz e efetivo com que podemos conciliar os ânimos de seus pais e parentes" (VIEIRA, 1947a [1656], p. 464). Dois anos mais tarde, escrevia ao geral, insistindo que receber indivíduos no Maranhão era "um meio de unirmos a nós os ânimos de seus pais e parentes" (VIEIRA, 1940a [1658], p. 273). É claro que, para os moradores, como já dissemos, os colégios representavam uma oportunidade ímpar para que seus filhos tivessem acesso ao ensino, algo difícil na América portuguesa. Mas já em 1660, o padre Vieira lamentou a morosidade da cúria generalícia com respeito a um futuro noviciado na Amazônia, queixando-se que "nos faltam as respostas [às solicitações enviadas], e particularmente sobre este ponto com grande sentimento nosso, e perda de alguns bons sujeitos, que puderam servir a Companhia, e, desesperados, aplicam a vocação a outras Religiões" (VIEIRA, 1940b [1660], p. 278).

Afamada por seu ensino, a Companhia de Jesus recebia pedidos dos próprios moradores do Maranhão para que fundasse escolas em diversas capitanias. Tais demandas, sempre laudatórias ao empenho docente jesuítico, por um lado demonstram o estado de precariedade no qual se encontrava o ensino no Maranhão e Pará; por outro, apresentam a preocupação da própria Coroa em resolver tal situação, uma vez que tais solicitações eram examinadas pelo próprio Conselho Ultramarino. Assim, por exemplo, no início da década de 1690, os oficias da Capitania do Pará se queixavam ao rei do não cumprimento da ordem régia passada em 20 de abril de 1688, dirigida ao superior da missão e ao reitor do 
Colégio de Santo Alexandre, que determinava a abertura de escolas que ensinassem aos filhos dos moradores tanto gramática quanto filosofia (Consulta do Conselho Ultramarino, 1690; Sobre o que escreveram..., 1690). Já entrado o século XVIII, os moradores do Pará se viam às voltas com o mesmo problema, razão pela qual mais uma vez recorreram ao rei. Agora, todavia, o parecer do Conselho Ultramarino não era nada favorável aos intentos de se fundar uma escola naquela capitania, dando a primazia para tal empreendimento à cidade de São Luís, "por ser povoação mais civilizada". Tratava-se, mais uma vez, de um decreto anterior que ordenava a construção de "um seminário na cidade do Pará para nele se educarem e doutrinarem alguns moços índios". Para tanto, foram ouvidos Cristóvão da Costa Freire (ex-governador do Estado) e João Maia da Gama (então governador do Maranhão); ambos foram favoráveis àquela empresa. Contudo, o Conselho, valendo-se de documentos anteriores, declarou em seu parecer que

Acrescendo agora as informações dos dois governadores que não diferem
muito na substância deste negócio (...), e acrescenta somente este
Conselho que o seminário será mais conveniente que se funde na cidade
de São Luís do Maranhão, por ser povoação mais civilizada que a do Pará
e mais apartada do tráfego e comércio dos índios (Satisfaça ao que S.M.
ordena...1723).

Nada obstante aos esforços das duas principais cidades do Estado, Belém e São Luís, de igual modo outras de menor envergadura também se mostravam interessadas nas escolas dos padres. Nesse sentido, exemplar é o caso da vila de Tapuitapera. É que os oficiais da Câmara da Vila de Santo Antonio de Alcântara (ou Tapuitapera) haviam requerido ao rei, por meio do Conselho Ultramarino, licença para que os padres da Companhia de Jesus fundassem naquela vila um "domicílio, por muito do serviço de Deus que nela haja quem doutrine, e ensine os filhos daqueles moradores assim os bons costumes, como as boas letras, por não terem para isso mestre algum". Na verdade, pela Consulta, a questão era um pouco mais complexa; isto porque, havia os mestres, só que a qualidade do ensino deles era considerada duvidosa. É que lá já estavam os mercedários e carmelitas com os seus conventos. Todavia, como se dizia na consulta

E porque estas utilidades [ensino] se não achavam nos dois conventos do Carmo e Mercês que há naquele povo, lhe pediram, e rogaram os oficiais da Câmara, e mais moradores com grandes instâncias fizessem aquela fundação que lhe parecia muito conveniente e necessária visto a repugnância que havia nos mais conventos para ensinar aos filhos daqueles moradores (Sobre o que escreve o Governador..., 1715).

Clara está a distinção entre a Companhia e as outras ordens religiosas. Diferença que se revela mais patente ainda no parecer final da consulta que apresenta ao rei a necessidade de se construir aquele hospício "e que nele assistam somente os religiosos da Companhia de Jesus, para ensinarem a ler e escrever, e o latim, e a doutrina cristã" já que, como visto anteriormente, era notório o "pouco préstimo que têm naquela mesma vila os religiosos das outras religiões como representa o governador e os moradores da mesma vila de Tapuitapera" (Sobre o que escreve o Governador..., 1715).

Apesar das repetidas restrições da cúpula da Companhia em aceitar pessoas nascidas na América portuguesa, as esperanças do padre Vieira em parte se concretizaram, já que pelo menos alguns portugueses nascidos no Maranhão foram recebidos na Ordem (o noviciado, de qualquer modo, teria que esperar). Entretanto, de acordo com Dauril Alden, à diferença do México e do Peru, “é improvável que os membros nascidos no Brasil tenham 
constituído a maioria" nas missões da América portuguesa. Na Missão do Maranhão, inclusive, ao longo do tempo, o número de locais até diminuiu (ALDEN, 1996, p. 261). Assim, nas décadas de 1650 e 1660, a porcentagem dos inacianos luso-brasileiros, isto é, daqueles nascidos na América portuguesa de pais portugueses, oscilou em volta de dez por cento. No decênio seguinte, ela caiu para, em média, seis por cento, mas chegou a seu auge nos anos de 1680, atingindo quase dezessete por cento. Após a expulsão dos jesuítas de São Luís, em 1684, a porcentagem dos "nativos" chegou mesmo a vinte e oito por cento, mas trata-se de uma circunstância excepcional. Desde 1688, com a chegada sucessiva de neo-missionários europeus (sobretudo portugueses), os luso-brasileiros não ocuparam mais do que dez por cento do total dos jesuítas na Missão, sendo a tendência declinante. A porcentagem dos padres e irmãos não-portugueses - em grande parte, originários ou da península itálica ou de regiões de fala alemã - teve um desenvolvimento parecido, sendo sempre um pouco superior à dos luso-brasileiros (ARENZ, 2010, p. 418-420).

Alguns dos candidatos "autóctones" recebidos na ordem no Estado do Maranhão e Pará foram despedidos ou simplesmente abandonaram a Ordem, mas outros permaneceram nela e se ordenaram sacerdotes. Esse foi o caso dos padres Antônio Pereira, ao qual nos referimos antes, e do padre Manuel Borba. O padre Pereira era "natural do Maranhão" e chegou a ser vice-superior da Missão do Maranhão. Em um catálogo escrito depois da expulsão de 1684, o padre Pereira aparece como vice-superior da missão, e como um dos dez "sacerdotes" do Maranhão, talvez professo de quatro votos (Catalogus Sociorum..., 1684, fl. 375). O que se pode juntar das esparsas notícias dele na crônica do padre Bettendorff é que foi aceito como "irmão estudante" e, depois da expulsão de 1661, foi estudar ao Brasil. Provavelmente do Brasil viajou a Portugal, já que quando o padre Bettendorff assumiu o reitorado do colégio do Maranhão, encontrou ao padre Pereira ainda como estudante e recém-chegado de Lisboa. Depois de sua ordenação, o religioso foi nomeado mestre de noviços, como vimos, e pregador do colégio de São Luís, além de missionário. O padre Bettendorff refere-se a ele como pregador do colégio do Maranhão. Professo de quatro votos, no livro dos óbitos da igreja de São Francisco Xavier é qualificado de "insigne língua e fervente missionário" (Livro dos obitos dos religiozos..., 1737, fl. 3v). No início dos anos 1680, em meio a fortes agitações devido a uma visitação muito contestada - a nomeação do Visitador foi reconhecida como ilícita - e a crescente resistência dos colonos, o padre Antônio Pereira exerceu a função de reitor do colégio de Belém (BETTENDORFF, 1990, p. 338). Ele morreu numa missão no Cabo do Norte, junto com seu companheiro, padre Bernardo Gomes, evento que ocasionou uma guerra contra os índios (MELO, 2008, p. 31-49). A trágica morte do padre Pereira nas mãos dos índios, deu ocasião ao padre Vieira para novamente reiterar a importância dos religiosos recebidos na terra, em carta a Roque Monteiro Paim, ao comentar que havia falecido "o maior sujeito que lá tínhamos" (VIEIRA, 1997e [1691], p. 637). Significativamente, nos anos 1670, o superior, padre Consalvi, encarregou ao padre Pereira que se ocupasse da educação de quatro candidatos, todos eles naturais do Maranhão (BETTENDORFF, 1990 [1698], p. 222, 303-304, 312, 324). Em 1688, alguns meses após a sua morte, ele consta no catálogo dos religiosos como superior da Missão. Tudo indica que a patente de nomeação foi enviada pela a cúria generalícia em Roma no ano anterior quando o padre ainda estava vivo (Catalogo dos Relig. ${ }^{\text {os }}$..., 1688, fl. 32v).

Em 1676 e 1677, o padre Consalvi, "pelos poderes que tinha alcançado" admitiu quatro indivíduos no noviciado. Dois deles, segundo o padre Bettendorff eram "naturais da terra"; os outros "naturais de São Luís" (BETTENDORFF, 1990 [1698], p. 316, 312). Eram Manuel Borba, Diogo da Costa, João da Silva e Baltasar Ribeiro (Cathalogo dos 
sogeitos..., [1748], fl. 480v). Todos eles foram ordenados sacerdotes. No catálogo de 1688, Diogo da Costa aparece como "coadjutor espiritual", Baltasar Ribeiro "estuda teologia" e Manuel Borba é "teólogo e filósofo". Não há nenhuma referência aos graus de João da Silva (Catalogo dos Relig. ${ }^{\text {os }}$..., 1688, fl. 32-32v). No catálogo de 1689, Diogo da Costa, João da Silva e Baltasar aparecem já como ordenados, o primeiro professo de três votos (Catalogo dos Relig. ${ }^{\text {os }}$..., 1689, fl. 22). No catálogo de 1697, são somente citados Diogo da Costa (vice-reitor do colégio do Maranhão) e João da Silva (vice-reitor do colégio do Pará), os dois como formatus, mas sem profissão de quatro votos (Brasilis. Maragnonen..., 1697, fl. 377v).

Dentre todos eles, o caso do padre Manuel Borba é muito significativo, pois era filho do capitão Manuel Duarte, "irmão" da Companhia por carta de irmandade. João Lúcio de Azevedo chamou a atenção para estes irmãos, lembrando que "tem sido ponto de dúvida se no instituto jesuítico, como em outras ordens religiosas, existem filiados sem hábito. Mesmo entre os escritores da casa variam as opiniões". Este historiador cita inclusive um documento que demonstra que uma das vantagens de ser irmão era a de ser enterrado na casa dos padres (AZEVEDO, 1931, p. 241). As cartas de irmandade que os jesuítas ligados à Missão do Maranhão concederam na Amazônia e na corte, às vezes por determinação de Roma, pareciam uma espécie de recompensa pelos favores e apoio recebido. Por outro lado, Manuel Borba era cunhado de Eugênio Ribeiro, um dos líderes da chamada "revolta de Beckman", ocorrida em 1684. Deixando de lado essas interessantes relações de parentesco, o fato é que Manuel Borba aparece como sacerdote nos catálogos da Companhia no Maranhão (Catalogo dos Relig. ${ }^{\text {os }}$..., 1688, fl. 32v). Teria voltado do reino ao Maranhão em 1687 (Cathalogo dos sogeitos...[1748], fl. 481v). Entretanto, não foi aprovado para professo do quarto voto pelo que consta do seu exame ad gradum, em 1685, se, como nos parece, se trata do mesmo Manuel Borba, nascido em Tapuitapera (ou Alcântara) (Suffragia examinorum ad gradum, s.d.). Tudo é ainda mais interessante quando lembramos que o padre Borba foi missionário na aldeia de Gurupatiba, em pleno sertão e que, portanto, devia saber a língua, já que era nascido na terra, justamente um dos principais argumentos do padre Vieira ao defender o noviciado do Maranhão. Não sem razão, mesmo anos depois de deixar o Maranhão, o padre Vieira escreveu ao superior da missão, padre Consalvi, insistindo na importância de se receber gente da terra, "natural do clima" (VIEIRA, 1947b [1677], p. 467).

O cunhado do padre Manuel Borba, Eugênio Ribeiro, foi um dos líderes do motim de 1684, durante o qual parte da população da cidade de São Luís se revelou contra a instituição do estanco - monopólio de comércio estabelecido pela Coroa com um grupo de comerciantes do reino. $\mathrm{O}$ objeto da ira dos moradores não foi somente o estanco, senão também os padres da Companhia de Jesus, que, pelas leis do ano de 1680, haviam obtido novamente o controle sobre as aldeias de índios livres no Estado do Maranhão (LISBOA, 1976, p. 425-490; AZEVEDO, 1999, p. 101-121; COUTINHO, 2004; MACNICOLL, 1978; LIBERMAN, 1983; CHAMBOULEYRON, 2006; CAETANO, 2009; ARENZ, 2010, p. 382-388). Eugênio Ribeiro, um dos mestres e procuradores do povo, foi preso quando se apresentava juntamente com Tomás Beckman, em Lisboa, frente às autoridades reais, para explicar as razões da sedição.

Segundo o padre Bettendorff, o padre Borba, que estudava em Évora, se dirigiu a Lisboa, "acabado seu curso", para interceder pelo cunhado na Corte. Aparentemente, graças à intervenção do padre Borba e do próprio padre Bettendorff, Eugênio Ribeiro escapou das piores penas - a forca ou o exílio ao Rio de Janeiro ou Angola - e recebeu 
uma pena menos grave, o desterro a Pernambuco. Já o sogro de Eugênio Ribeiro, e pai do jesuíta Manuel Borba, Manuel Duarte, era morador da vila de Tapuitapera, capitania próxima a São Luís. Significativamente, como sugere o padre Bettendorff, Manuel Duarte foi um dos que se opuseram ao motim de 1684, quando os rebeldes de São Luís se dirigiram a Tapuitapera para tentar convencer os moradores dela a se juntarem a eles. De acordo com a Crônica do padre Bettendorff, pouco depois da rebelião, alguns dos padres expulsos tiveram que voltar ao Estado, pois seu barco afundara e os religiosos foram presos e torturados por piratas. Depois de conseguir escapar, os padres chegaram a Tapuitapera, onde foram acolhidos pela população. Segundo o padre Bettendorff, vários foram

Os que mais se assinalaram em fazer bem aos padres, foram, depois do senhor superintendente, Antônio de Albuquerque, o vigário João Maciel, o capitão-mor Henrique Lopes, o capitão-mor Jacinto de Araújo, Pedro da Rocha, e com singular afeto de amor, o capitão Manuel Duarte, irmão da Companhia, por carta de irmandade (BETTENDORFF, 1990, p. 388).

A formação de religiosos nascidos na terra, parte importante das atividades educativas dos padres inacianos, estava, portanto, intimamente ligada às relações políticas que os próprios jesuítas construíram no interior da sociedade colonial.

Lugar privilegiado do ensino dos filhos dos moradores eram os colégios que a Companhia fundou nas cidades de Belém e de São Luís. Se por um lado, os colégios têm que ser compreendidos como um lugar de formação, por outro lado, constituíram um lugar de efetivação e financiamento da própria missão. Assim, novamente, um espaço em princípio caracterizado como lugar de ensino também tem que ser entendido como um lugar de consolidação do próprio apostolado da Companhia e do seu poder no interior das comunidades portuguesas.

Segundo o padre Bettendorff, em 1615, a expulsão dos franceses que estavam em São Luís teve lugar com a chegada, em 1622, de uma expedição vinda de Pernambuco liderada pelo capitão-mor Alexandre de Moura e composta pelos padres jesuítas Luís Figueira, Lopo de Couto e Bento Amado (Benedetto Amodei), e mais duzentos índios liderados pelo seu principal Gregório Migtagoaya. Aproveitando a dívida que aquele capitão tinha com a Companhia de Jesus, logo requereu o padre Figueira quarenta braças de terra em quadra, logrando êxito. Aproveitou também seu bom relacionamento com o dito principal Migtagoaya e sem demora, com o auxílio deste e seus vassalos índios, iniciou, em São Luís, a edificação do colégio de Nossa Senhora da Luz naquele terreno (BETTENDORFF, 1990, p. 43). Já o início das construções do colégio de Santo Alexandre, em Belém, demoraria um pouco mais, pois a Companhia de Jesus só se estabeleceu de fato na cidade em 1652, com o assento dos padres João de Souto Maior e Gaspar Fragoso.

Nesse mesmo ano alcançaram dos padres mercedários um terreno na Campina, para que nele erguessem uma primeira habitação, como de fato fizeram. Todavia, o terreno era impróprio para a construção de um colégio, o que levou o padre Souto Maior a comprar do casal Gaspar Cardoso e Joana de Melo um terreno vizinho ao forte da cidade, e logo "lançou as medidas dos alicerces e obras, para o Colégio" (BETTENDORFF, 1990, p. 74). Essa mudança ensejou inclusive a reação dos moradores que se queixaram em carta ao rei de que os padres tinham deixado um "sítio muito bom, capaz e bastante para fundarem casa", instalando-se junto à fortaleza, "afastado dela somente 20 braças". Embora o 
Conselho Ultramarino tenha advertido ao rei que havia que se "impedir toda obra que pudesse vir a ser perigo àquela fortaleza", e devia se buscar lugar apropriado para a "igreja e mosteiro" dos padres, o fato é que os padres ali acabaram se instalando, fazendo "padrasto" ao forte (Consulta do Conselho Ultramarino, 1655).

A construção dos colégios, entretanto, não se fizera somente nesses princípios da missão. Na verdade, eles eram construídos pouco a pouco, corredor por corredor, devido aos altíssimos recursos que tais obras demandavam. Prédios mais sólidos só foram erguidos - suscitando as suas plantas muitos debates entre os padres responsáveis - nas décadas 1670 a 1690, com uma interrupção em razão do levante em São Luís em 1684 (LEITE, 1943a, p. 118-122). Entretanto, o resultado final ficou a contento - visto que houve ainda uma última fase de reformas e melhoramentos nos anos de 1710 e 1720 (SANTOS, 1951, p. 108) -, pois, não sem razão, após a expulsão dos jesuítas em 1759 e tantas outras reviravoltas, os mesmos colégios ostentam, na atualidade, os títulos de Sé Catedral de São Luís e Museu de Arte Sacra de Belém do Pará.

Por outro lado, os colégios funcionaram como centros gerenciadores dos bens temporais da Ordem, ficando estes bens sempre atrelados aos colégios. Assim, a ereção de um colégio jesuítico já era pensada de modo a desenvolver atividades temporais/comerciais, para além do ensino dos moradores, indígenas e religiosos. Nesse sentido, José Antônio Araújo lembra que as construções jesuíticas seguiam o mesmo estilo aplicado na ereção de conventos e mosteiros - disposição em quadra ou retângulo - de modo a formar um ou mais pátios interiores. $\mathrm{O}$ pátio teria como objetivo $\mathrm{o}$ descanso/reflexão dos religiosos, daí eles serem rodeados de galerias que permitiam a sombra. Os pátios jesuíticos, todavia, não possuíam galerias, e faziam fronteira diretamente com os muros da construção (igreja, colégio...). Essa falta de "sossego e recolhimento" e a iluminação direta nos pátios jesuíticos estavam intimamente ligadas a suas funções para o colégio: circulação ou meio termo entre reclusão e a vida ativa da Companhia (ARAÚJO, 2000 , p. 65-72). Nesse sentido o padre Serafim Leite esclarece que "no Pará, junto ao colégio, no pátio inferior dele, construíram-se casas e armazéns para recolher aqueles gêneros, vindos das diversas missões do interior" (LEITE, 1943b, p. 171).

Segundo o padre Serafim Leite, somente os "colégios e as casas de formação" possuíam bens próprios "de cujos rendimentos se sustentem" (LEITE, 1943b, p. 167). Segundo o padre Leite, esta foi uma determinação de Santo Inácio a partir das constituições jesuíticas, com o intuito de manter a pobreza dos padres e irmãos da Companhia. Diz o autor que "somente os colégios, como entidade moral", podiam possuir "os meios indispensáveis para a consecução do seu objetivo comum" (LEITE, 1938, p. 107). As atividades econômicas em torno de um colégio jesuítico envolviam não somente os seus religiosos como também os demais moradores da colônia. Criação de gado, cultivo de diversas culturas, expedições ao cravo e cacau e descimentos de indígenas eram algumas atividades desenvolvidas pelos missionários dos colégios.

Paulo de Assunção enfatiza a necessidade de a Companhia de Jesus se integrar na sociedade colonial, realidade diversa da de Portugal. Ele ressalta que "na América portuguesa não era possível obter rendas de mosteiros ou de terras coutadas", o que exigia maior criatividade da Ordem visando a sua manutenção (ASSUNÇÃO, 2004, p. 151). Neste sentido, Dauril Alden lembra que os jesuítas cultivavam várias lavouras em suas fazendas, lavouras indígenas e européias, sendo a produção destinada "principalmente ao sustento dos padres e seus pupilos, mas os excedentes eram vendidos a pessoas estranhas à 
Ordem" (ALDEN, 1970, p. 35). Paulo de Assunção, ao citar uma observação de Jorge Couto, lembra que houve, no século XVI, um embate entre os padres Luís da Grã e Manuel da Nóbrega. Para o padre Grã, o ideal de pobreza da Companhia devia ser seguido de modo que a Ordem não viesse a incorporar bens de raiz e nem utilizar mão-de-obra escrava. Já para o padre Nóbrega os bens materiais e a posse de escravos eram algo imprescindível para o desenvolvimento da Ordem. O padre Nóbrega recorria ao fato de as Constituições jesuíticas permitirem a posse de bens pelos colégios. A congregação provincial de 1568 confirmou o papel dos colégios jesuíticos postulando que era vital para o bem da Ordem que eles possuíssem "fazendas e terras" e também pudessem comprar escravos, tudo para "continuar a obra missioneira" (ASSUNÇÃO, 2007, p. 61-62).

Quando a Companhia de Jesus chegou a São Luís do Maranhão, em 1615, logo surgiu a preocupação pela subsistência dos padres, o que, segundo o cronista padre Domingos de Araújo, foi resolvido com a doação ao padre Figueira das terras de Anindiba pelo casal Pero Dias Moreno e Apolônia Bustamante, terra onde teve o colégio de Nossa Senhora da Luz "farinha, legumes, e outras coisas, que muito bem servem ao mesmo colégio", como relatava o padre Domingos de Araújo, nas primeiras décadas do século XVIII (ARAÚJO, c.1720, fl. 106). Mas a partir das primeiras doações, é possível afirmar que o patrimônio dos colégios e as atividades econômicas a eles vinculadas cresceram incessantemente. Após o levante de 1661, o padre Bettendorff buscou, em sua função de superior local, afirmar a base econômica da casa central da Missão, em São Luís, com a construção de um novo engenho de açúcar, plantio de laranjeiras e bananeiras (inclusive duas espécies originárias da China), reforma das salinas, aumento do rebanho de gado num terreno no vale do rio Mearim e compra de alguns escravos negros (BETTENDORFF, 1671b, fl. 266v; 1990, p. 225). De fato, garantir o sustento de um número crescente de docentes e discentes que viviam nos colégios foi uma das grandes preocupações dos superiores e ecônomos. Os padres Bettendorff, reitor de São Luís, e Consalvi, superior da Missão, escreveram, em 1679, a este respeito aos responsáveis da Companhia em Roma, solicitando com urgência mais subsídios (BETTENDORFF, 1990, p. 436; 1679, fl. 62v; CONSALVI, 1679, fl. 66v; ARENZ, 2010, p. 432).

Nesse contexto, a posse de terrenos constituiu um constante pomo de discórdia com outros religiosos ou com alguns moradores. Em sua Crônica, o padre luxemburguês relata a disputa entre mercedários e jesuítas pelas terras de "São Marcos", apropriadas para se fazer curral de gado. O cronista jesuíta defendia que era necessário comprar terras de águas boas para se dar de beber ao gado, fronteiras ao curral dos jesuítas do Colégio de Nossa Senhora da Luz. A mesma terra já estava sendo ocupada pelo curral de gado dos mercedários. A contenda só foi resolvida com a compra destas terras pelo próprio padre Bettendorff de Maria Sardinha, antiga dona das terras (BETTENDORFF, 1990, p. 263264).

No Cartório Jesuítico, há variada documentação sobre os currais de gado dos colégios de Nossa Senhora da Luz e de Santo Alexandre; são geralmente traslados pedidos pelos padres desses colégios para se resolverem litígios que envolviam os colégios e particulares em torno da propriedade. Exemplar nesse sentido é o traslado de uma data de terra passada, em 1709, por Gonçalo de Souza de Macedo, ao reitor do colégio de Santo Alexandre, padre Inácio de Ferreira. Ao reitor foram passadas duas léguas na Ilha Grande de Joanes nas "quais duas léguas poderão usar e servir-se para a pastagem e sustento do sobredito gado [do colégio de Santo Alexandre]" (Tt. ${ }^{\circ}$ dos curraes do Marajó, s.XVIII). ${ }^{9}$ 
De outro lado, o padre Leite ainda levanta a questão das expedições ao sertão em busca ao cravo e cacau. Segundo o historiador da Ordem, o cravo e cacau eram enviados a Lisboa por meio do colégio do Pará e com o "produto" destas drogas se pagavam algumas dívidas e caso estas não existissem "punha-se a juros para as despesas futuras, imediatas" (LEITE, 1943b, p. 168). O padre Serafim Leite lembra que o padre Vieira era contrário a tais expedições, pois para ele a coleta desses produtos poderia causar embaraços para a Ordem já que o cravo e cacau não eram fruto do trabalho dos jesuítas. Com efeito, no ano de 1688, o padre Vieira, exercendo a função de visitador do Brasil e do Maranhão, proibiu aos "superiores e missionários" a ida a tais expedições. No entanto, ou "pela mudança de superiores locais ou por terem surgidas novas razões, recomeçaram as idas ao cravo e cacau" (LEITE, 1949, p. 292-293). Produtos ou não (como era o caso do cravo e do cacau do sertão) da fazenda jesuítica eles eram vendidos pelos padres, como "produtos do trabalho e da terra". Tal venda era necessária para construção e manutenção de algumas obras como residências e igrejas, e para as despesas diversas como "salários, descimentos, catequese". João Lucio de Azevedo ao fazer menção aos livros de registro do governo do Pará expõe que "em 1740 e nos anos próximos" foram os jesuítas a Ordem que mais se destacou nas expedições ao cacau. O autor afirma que "os jesuítas costumavam mandar, no mês de outubro, dezoito canoas ao cacau; em segundo lugar vinham na lista os religiosos do Carmo, com o número de nove ou dez" (AZEVEDO, 1930, p. 236-237).

Como se sabe, as atividades econômicas da Companhia de Jesus logo causaram diversos embaraços à Ordem (DIAS, 2008, p. 108-140), que em finais da década de 1750, ao ser expulsa dos territórios de Portugal, acabou tendo seus inúmeros bens confiscados pela Coroa (SOUZA JR, 2009, p. 218-260). Ao se referir ao comportamento dos jesuítas da Missão do Maranhão em uma carta de 28 de julho de 1729, o rei alertava ao governador do Maranhão, Alexandre de Souza Freire, que "a ocupação de missionários que se lhes encarrega dista muito da de senhores que se arrogam e muito mais da de negociantes que com escândalo da Religião há noticia exercitam" (Communica que o rei mandou..., 1905 [1729]).

É preciso destacar que a Companhia de Jesus recebeu alguns privilégios específicos para o Estado do Maranhão, que permitiam viabilizar ainda mais as suas atividades. $\mathrm{O}$ padre Bento da Fonseca elenca em um único capítulo de seus "Apontamentos" alguns dos vários benefícios que a Ordem recebeu. $\mathrm{O}$ religioso relata, por exemplo, a proposta feita por Dom João IV ao padre Vieira de "consignar rendas bastante para a fundação de um colégio que queria mandar fundar no Maranhão". O padre Vieira teria declinado desse auxílio ao levar em consideração a "necessidade que S.M. tinha de dinheiro para a conservação e sustentação das guerras que por aquele tempo tínhamos com Castela por causa da Aclamação". No entanto, o mesmo religioso teria aceitado do monarca a consignação para o sustento "de cada um dos religiosos de 35 mil réis" e mais três aldeias "que fossem privativas de nossa administração". À côngrua para cada um dos religiosos, observa o cronista, acrescentou Dom Pedro II, em 1680, "mais 250 mil réis com a obrigação de termos outros dez religiosos". O cronista narra que os monarcas consideraram necessário acrescentar posteriormente "mais ou menos dez religiosos [...] para o sustento dos quais mandou S.M. dar todos os anos 350 mil reis" (FONSECA, s.d., fl. 102v-104).

A ereção dos colégios, assim, estava articulada a um sem número de outras atividades e relações, notadamente de natureza temporal, uma vez que a sustentação da própria missão estava atrelada aos colégios, que assumiam assim um papel que ia além da formação dos filhos dos moradores e dos religiosos. 
Entender o papel do ensino dos jesuítas na Amazônia colonial não deve se restringir apenas às atividades educativas propriamente ditas. $\mathrm{O}$ ensino organizado pela Companhia de Jesus, para além de uma tradição que se conformou dentro da Ordem, deve ser compreendido a partir das formas pelas quais os jesuítas se inseriram no universo colonial. Assim, é preciso recuperar o sentido político que assumiram as classes nas cidades e vilas, pois elas permitem melhor entender o lugar que a Companhia de Jesus construiu para si na Amazônia colonial. Nesse sentido, o processo demorado para introduzir todas as etapas do sistema educativo jesuítico no Estado do Maranhão e Grão-Pará - mais de quarenta anos (das reivindicações de Vieira às primeiras ordenações sacerdotais) - se explica tanto pela complexidade da conjuntura política envolvente (tensões que marcaram a constituição da sociedade colonial) como pela precariedade econômica (que afetou todo o mundo colonial seiscentista). Por outro lado, é preciso compreender as múltiplas maneiras por meio das quais os padres souberam consolidar a sua própria instituição na América, entendendo, igualmente, as dimensões econômicas políticas do apostolado dos religiosos da Companhia de Jesus na Amazônia colonial.

Fontes

ARAÚJO, Domingos de, SJ. Chronica da Companhia de Jesus da missam do Maranham [1720]. Biblioteca Pública de Évora, códice CXV/2-11, fl. 209r-331v.

BETTENDORFF, J.FL., SJ. Crônica da missão dos padres da Companhia de Jesus no Estado do Maranhão [1698]. Belém: SECULT, 1990.

BETTENDORFF. Ao superior geral Gian Paolo Oliva. São Luís, 11 de agosto de 1665. Archivum Romanum Societatis Iesu, cód. Bras [Brasile] 26, fl. 12-17v.

BETTENDORFF. Compromisso e Regras da Congregção de Nossa Senhora da Luz e do Terzo. São Luís, 12 de setembro de 1670. Archivum Romanum Societatis Iesu, cód. Fon Ges [Fondo Gesuitico] 145 V, fl 2-8.

BETTENDORFF. Catalogus Missionis Maranhonii. 1671 [1671a]. Archivum Romanum Societatis Iesu, cód. Bras [Brasile] 27, fl. 2-2v.

BETTENDORFF. Ao superior geral Gian Paolo Oliva. São Luís, 21 de julho de 1671 [1671b]. Archivum Romanum Societatis Iesu, cód. Bras [Brasile] 9, fl. 259-267v.

BETTENDORFF. Ao superior geral Gian Paolo Oliva. São Luís, 7 de maio de 1678. Archivum Romanum Societatis Iesu, cód. Bras [Brasile] 26, fl. 45-48v.

BETTENDORFF. Ao superior geral Gian Paolo Oliva. São Luís, 18 de abril de 1679. Archivum Romanum Societatis Iesu, cód. Bras [Brasile] 26, fl. 62-63v.

BETTENDORFF. Ao superior geral Gian Paolo Oliva. S/1, 10 de abril de 1681. Archivum Romanum Societatis Iesu, cód. Bras [Brasile] 3 II, fl. 146-147v.

Brasilis. Maragnonen. Catalogus Sociorum missionis Maragonensis. 1697. Biblioteca Pública de Évora, códice CXV/2-13, fl. 376v-380r.

CARVALHO, J. de S. e. Representação de Jorge de Sampayo e Carvalho contra os Padres da Companhia de Jesus, expondo os motivos que teve o povo para os expulsar do Maranhão. [1661], Revista do Instituto do Ceará, v. XXXV, pp. 8-16, 1921.

Catalogo dos Relig. ${ }^{\text {os }}$ da Missaõ. 1689. Biblioteca Pública de Évora, códice CXV/2-11, fl. 22-23.

Catalogo dos Relig. ${ }^{\text {os }}$ do Mar. ${ }^{\text {aõ }}[\ldots]$ e bom p. ${ }^{\text {a }}$ not. ${ }^{\text {as }}$. 1688. Biblioteca Pública de Évora, códice CXV/2-11, fl. 32-33.

Catalogus Sociorum qui in Missione Maragonensi ante eorum expulsionem numerabantur; et modo post eandem numerantur anno 1684. Biblioteca Pública de Évora, códice CXV/213, fl. 375-376. 
Cathalogo dos sogeitos q. forão p. ${ }^{a}$ o Maranhão desde 1615 [1748]. Biblioteca Pública de Évora, códice CXV/2-13, fl. 478r-489v.

Communica que o rei mandou ao padre provincial da Companhia de Jesus conhecer dos abusos de seus subordinados. Lisboa, 28 de julho de 1729. Anais da Biblioteca e Arquivo Público do Pará, Belém, t. IV, p. 55, 1905.

CONSALVI, Pier Luigi, SJ. Ao superior geral Gian Paolo Oliva. São Luís, 18 de abril de 1679, Archivum Romanum Societatis Iesu, cód. Bras [Brasile] 26, fl. 66-67v.

Consulta do Conselho Ultramarino. 19 de maio de 1655. Arquivo Histórico Ultramarino, Pará (Avulsos), caixa 2, doc. 94.

Consulta do Conselho Ultramarino. 20 de setembro de 1690. Arquivo Histórico Ultramarino, Pará (Avulsos), caixa 3, doc. 286.

FONSECA, B. da, SJ. Apontamentos para a chronica da Companhia de Jesus no Maranhão. Biblioteca Nacional de Portugal, Reservados, CoD 4516.

GORZONI, João Maria, SJ. Ao superior geral Gian Paolo Oliva. Pará, 20 de agosto de 1682, Archivum Romanum Societatis Iesu, cód. Bras [Brasile] 26, fl. 95-96v.

Livro dos obitos dos religiozos da Comp. ${ }^{\text {a }}$ de Jesus pertencentes a este Coll. ${ }^{\circ}$ de S. ${ }^{\text {to }}$ Alexandre $=$ anno 1737. [1660-1737]. Biblioteca Nacional de Portugal, Coleção Pombalina, $n^{\circ} 4$.

Satisfaça ao que S.M. ordena sobre se fundar um seminário na cidade do Pará. 28 de setembro de 1723. Arquivo Histórico Ultramarino, códice 209, fl. 14.

Sobre o que escreve o Governador e Capitão Geral do Estado do Maranhão Cristovão da Costa Freire acerca da informação que se lhe pediu para os padres da Companhia de Jesus fazerem um hospício na vila de Tapuitapera. 10 de janeiro de 1715. Arquivo Histórico Ultramarino, códice 274, fl. 237-238.

Sobre o que escreveram os oficiais da Câmara do Pará acerca dos Padres da Companhia não haverem dado execução a ordem que lhes foi para abrirem estudos naquela capitania. 20 de dezembro de 1690. Arquivo Histórico Ultramarino, códice 274, fl. 69.

Suffragia examinorum ad gradum. Biblioteca Nacional de Portugal, Reservados, CoD 6835.

PERRET, Jódoco, SJ. Ao superior geral Gian Paolo Oliva. Belém, 10 de abril de 1679, Archivum Romanum Societatis Iesu, cód. Bras [Brasile] 26, fl. 61-61v.

Tt. $^{\circ}$ dos curraes do Marajó - Parâ Século XVIII. Arquivos Nacionais/Torre do Tombo, Cartório Jesuítico, maço 82, doc. 29.

VIEIRA, A., SJ. Ao padre provincial do Brasil [Francisco Gonçalves]. Lisboa, 14 de novembro de 1652. In: Cartas. Coordenadas e anotadas por João Lúcio de Azevedo. Lisboa: Imprensa Nacional/Casa da Moeda, vol. I, 1997a. p. 266-281.

VIEIRA. Ao provincial do Brasil. Maranhão, 22 de maio de 1653. In: Cartas, vol. I, 1997b. p. 306-343.

VIEIRA. Ao provincial do Brasil [Francisco Gonçalves]. Maranhão, [1654]. Cartas, vol. I, 1997c. p. 370-399.

VIEIRA. Ao provincial do Brasil. 1656. Brotéria, Lisboa, v. 45, fl. 4, p. 456-466, 1947a.

VIEIRA. Ao padre geral, Goswin Nickel. Maranhão, 10 de setembro de 1658. In: Novas cartas jesuíticas (de Nóbrega a Vieira). Organizadas por: LEITE, S., SJ. São Paulo: Companhia Editora Nacional, 1940a. p. 265-276.

VIEIRA. Ao padre geral, Goswin Nickel. Maranhão, 11 de fevereiro de 1660. In: Novas cartas jesuíticas (de Nóbrega a Vieira), 1940b. p. 277-281.

VIEIRA. Ao padre provincial do Brasil. Ibiapaba, $1^{\circ}$ de maio de 1660 , Cartas, vol. III, 1997d. p. 749-754. 
VIEIRA. Ao padre geral, Goswin Nickel. Rio das Amazonas, 18 de março de 1661. In: Novas cartas jesuíticas (de Nóbrega a Vieira), 1940c. p. 284-288.

VIEIRA. Ao superior do Maranhão. Lisboa, 10 de abril de 1677. Brotéria, Lisboa, v. 45, fl. 4, p. 466-469, 1947b.

VIEIRA. Ao superior Pedro Luís Consalvi. Lisboa, 2 de abril de 1680. In: Cartas do Padre Antônio Vieira. Organizadas por João Lúcio de Azevedo. Lisboa: Imprensa Nacional, 1971, tomo 3. p. 442-452.

VIEIRA. A Roque Monteiro Paim. Bahia, 2 de julho de 1691. Cartas, vol. III, 1997e. p. 636-640.

Bibliografia

ALDEN, D. Black robes versus white settlers: the struggle for "freedom of the Indians" in Colonial Brazil. In: PECHMAN, H. \& GIBSON, C. (Org.) Attitudes of colonial powers toward the American Indian. Salt Lake City: University of Utah Press, 1969. p. 19-45.

ALDEN, D. Aspectos econômicos da expulsão dos jesuítas do Brasil. In: KEITH, H.H. \& EDWARDS, S.F. (org.). Conflito e continuidade na sociedade brasileira. Rio de Janeiro: Civilização Brasileira, 1970, pp. 31-78.

ALDEN, D. El indio desechable en el Estado de Maranhão durante los siglos XVII y XVIII. América Indígena, México, v. XLV, n. 2, p. 427-446, 1985.

ALDEN, D. Indian versus black slavery in the state of Maranhão during the seventeenth and the eighteenth centuries, Bibliotheca Americana, Coral Gables, v. 1, n. 3, p. 91-142, 1984.

ALDEN, D. The making of an enterprise. The Society of Jesus in Portugal, its empire, and beyond. 1540-1750. Stanford: Stanford University Press, 1996.

ALMEIDA, A.F. de. The organisation of the Jesuit mission of Maranhão: António Vieira and the shaping of a missionary project, Archivum Historicum Societatis Iesu, Roma, v. LXXIV, f. 147, p. 91-118, 2005.

ALMEIDA, M.R.C. de. Trabalho compulsório na Amazônia: séculos XVII-XVIII. Revista Arrabaldes, Rio de Janeiro, v. I, n. 2, p. 101-117, 1988.

ARAÚJO, J.A.A. de. A quadra perfeita: um estudo sobre a arquitetura rural jesuítica. Rio de Janeiro: Madgráfica, 2000.

ARENZ, K.-H. De l'Alzette à l'Amazonie: Jean-Philippe Bettendorff et les jésuites en Amazonie portugaise (1661-1693). Saarbrücken: Éditions universitaires européennes, 2010.

ASSUNÇÃO, P. de. Negócios jesuíticos: a administração dos bens divinos. São Paulo: Edusp, 2004.

ASSUNÇÃO, P. Colégios jesuíticos e o servir a Deus: a experiência e o tempo ensinam tudo. Em Aberto, Brasília, v. 21, n. 78, p. 58-76, 2007.

AZEVEDO, J.L. de. Os jesuítas no Grão-Pará. Coimbra: Imprensa da Universidade, 1930. AZEVEDO, J.L. de. História de António Vieira. $2^{a}$ edição. Lisboa: Livraria Clássica, 1931, vol. I.

BAENA, A.L.M. Ensaio corográfico sobre a provincia do Pará. Pará: Typographia de Santos \& Menor, 1839.

BELLOTO, H.L. Trabalho indígena, regalismo e colonização no estado do Maranhão nos séculos XVII e XVIII. Revista Brasileira de História, São Paulo, v. 4, p. 177-192, 1982.

BRADING, D. "La patria criolla" y la Compañía de Jesús. Artes de México (los colegios jesuitas en la Nueva España), n. 58, p. 58-70, 2001. 
CAETANO, A.F.P. Entre drogas e cachaça: A política colonial e as tensões na América portuguesa (1640-1710). Macieó: EdUFAL, 2009.

CARVALHO JÚNIOR, A.D. de. Índios cristãos: a conversão dos índios na Amazônia portuguesa (1653-1769). 2005. Tese (Doutorado) - Campinas, Universidade Estadual de Campinas, 2005.

CHAMBOULEYRON, R. "Duplicados clamores". Queixas e rebeliões na Amazônia colonial (século XVII). Projeto História, São Paulo, n. 33, p. 159-178, 2006.

COELHO, M.C. Do sertão para o mar. Um estudo sobre a experiência portuguesa na América, a partir da Colônia: o caso do Diretório dos Índios (1751-1798). 2005. Tese (Doutorado) - Universidade de São Paulo, São Paulo, 2005.

COUTINHO, M. A revolta de Bequimão. $2^{a}$ edição. São Luís: Instituto Geia, 2004.

DELUMEAU, J. A confissão e o perdão: as dificuldades da confissão nos séculos XIII a XVIII. São Paulo: Companhia das Letras, 1991.

DIAS, C.L. Civilidade, cultura e comércio: os princípios fundamentais da política indigenista na Amazônia (1614-1757). 2009. Dissertação (Mestrado) - Universidade de São Paulo, São Paulo, 2009.

DIAS, J.S. Os "verdadeiros conservadores" do Estado do Maranhão: poder local, redes de clientela e cultura política na Amazônia colonial (primeira metade do século XVIII). 2008. Dissertação (Mestrado) - Universidade Federal do Pará, Belém, 2008.

FARAGE, N. As muralhas dos sertões. São Paulo: Paz e Terra, 1991.

GARCÍA-VILLOSLADA, R., SJ. Santo Inácio de Loyola. São Paulo: Loyola, 1991.

GROSS, S.A. Labor in Amazonia in the first half of the eighteenth century. The Americas, Washington, v. XXXII, n. 2, p. 211-221, 1975.

GUZMÁN, D. de A. A colonização nas Amazônias: guerras, comércio e escravidão nos séculos XVII e XVIII. Revista Estudos Amazônicos, Belém, v. III, n. 2, p. 103-39, 2008.

GUZMÁN, D. de A. Encontros circulares: guerra e comércio no Rio Negro (Grão-Pará), séculos XVII e XVIII. Anais do Arquivo Público do Pará, Belém, v. 5, t. 1, p. 139-65, 2006.

HAUBERT, M. L'Église et la défense des “sauvages”. Bruxelas: Académie Royale des Sciences D'Outre-Mér, 1964.

KIEMEN, M.C. OFM. The Indian policy of Portugal in the Amazon region, 1614-1693. Washington: The Catholic University of America Press, 1954.

LA ROCHE, J.R. La formation de l'enfant par les jésuites. L'exemple du collège d'Ocaña. In: REDONDO, A. (org.). Formation de l'enfant en Espagne au XVI et XVII siécles. Paris: Publications de la Sorbonne, 1996. p. 189-214.

LEITE, S., SJ. História da Companhia de Jesus no Brasil. Rio de Janeiro/Brasília: Portugália/INL, v. I (1938), III (1943a), IV (1943b), v. VII (1949).

LIBERMAN, M. O levante do Maranhão. Judeu Cabeça de Motim: Manoel Beckman. São Paulo: Centro de Estudos Judaicos/USP, 1983.

LIMA, A. da S. A guerra pelas almas: Alianças, Recrutamentos e Escravidão Indígena, (do Maranhão ao Cabo do Norte, 1615-1647). 2006. Dissertação (Mestrado) - Universidade Federal do Pará, Belém, 2006.

LISBOA, J.F. Crônica do Brasil colonial: apontamentos para a história do Maranhão. Petrópolis/Brasília: Vozes/INL, 1976.

MACLACHLAN, C, The Indian labor structure in the Portuguese Amazon, 1700-1800. In: ALDEN, D. (Org.). Colonial roots of modern Brazil. Berkeley/Los Angeles: The University of California Press, 1973. p. 199-230.

MACNICOLL, M.G. Seventeenth-Century Maranhão: Beckman's revolt. Estudos iberoamericanos, Porto Alegre, v. 4, n. 1, p. 129-140, 1978. 
MARQUES, J.F. Confesseurs des princes, les Jésuites à la cour de Portugal. In: GIARD, Luce \& VAUCELLES, Louis de, SJ (Org.). Jésuites à l'âge baroque (1540-1640). Grenoble: Jérôme Millon, 1996. p. 213-228.

MELO, V.S. de. "Aleivosias, mortes e roubos". Guerras entre indios e portugueses na Amazônia colonial (1680-1706). 2008. Monografia (Graduação) - Universidade Federal do Pará, Belém, 2008.

MELLO, M.E.A. de S. e. Desvendando outras Franciscas: mulheres cativas e as ações de liberdade na Amazônia colonial portuguesa. Portuguese Studies Review, Ontário, v. 13, n. 1, p. 1-16, 2005.

MELLO, M.E.A. de S. e. Para servir a quem quizer: apelações de liberdade dos índios na Amazônia Portuguesa. In: SAMPAIO, P. de Missão \& ERTHAL R. de C. (Org.). Rastros da Memória: histórias e trajetórias das populações indígenas na Amazônia. Manaus: EDUA, 2006. p. 48-72.

MELLO, M.E.A. de S. e. O Regimento das Missões: poder e negociação na Amazônia portuguesa. In: Clio, Recife, vol. 27, n. 1, p.46-75, 2009a.

MELLO, M.E.A. de S. e. Fé e império. Manaus: EdUA/FAPEAM, 2009b.

MONTEIRO, J.M. O escravo índio, esse desconhecido. In: GRUPIONI, L.D.B. (Org.). Índios no Brasil. São Paulo: Secretaria Municipal de Cultura, 1992a. p. 105-120.

MONTEIRO, J.M. Escravidão indígena e despovoamento na América portuguesa: S. Paulo e Maranhão. In: DIAS, J. (Org.). Brasil nas vésperas do mundo moderno. Lisboa: CNCDP, 1992b. p. 137-167.

OLIVEIRA, M. da C. de. Escravidão indígena na Amazônia colonial. 2001. Dissertação (Mestrado) - Universidade Federal de Goiás, Goiânia, 2001.

PERRONE-MOISÉS, B. Para conter a fereza dos contrários: guerras na legislação indigenista colonial. Cadernos Cedes, v. 30, p. 57-64, 1993.

PORRO, A. O povo das águas. Petrópolis: Vozes, 1996.

REIS, A.C.F. O Estado do Maranhão - catequese do gentio - rebeliões - pacificação. Rio de Janeiro: Departamento de Imprensa Nacional, 1950.

SANTOS, B.C.C. O pináculo do temp $(l)$ o. O sermão do padre Antônio Vieira e o Maranhão do século XVII. Brasília: EdUnB, 1997.

SANTOS, P.F. O barroco e o jesuítico na arquitetura do Brasil. Rio de Janeiro: Kosmos, 1951.

SARAIVA, A.J. O Pe. António Vieira e a liberdade dos índios. In: História e utopia. Lisboa: Ministério de Educação/Instituto de Cultura e Língua Portuguesa, 1992. p. 13-52.

SILVA, G. do L. Educação na Amazônia colonial. Manaus: Suframa, 1985.

SOMMER, B. Colony of the sertão: Amazonian expeditions and the Indian slave trade.

The Americas, Washington, v. 61, n. 3, p. 401-428, 2005.

SOUSA, J.O. Mão-de-obra indígena na Amazônia Colonial. Em Tempo de Histórias, Brasília, v. 6, p. 1-18, 2002.

SOUZA, J.C. de, SJ. Os jesuítas no Maranhão. São Luís: Fundação Cultural do Maranhão, 1977.

SOUZA JR, J.A. de. Tramas do cotidiano: religião, política, guerra e negócios no Grão-Pará do setecentos. Um estudo sobre a Companhia de Jesus e a política pombalina. 2009. Tese (Doutorado) - Pontifícia Universidade de São Paulo, São Paulo, 2009.

SWEET, D. A rich realm of nature destroyed: the middle Amazon valley, 1640-1750. 1974, 2 vols. Tese (Doutorado) - University of Wisconsin, Madison, 1974.

Revista HISTEDBR On-line, Campinas, número especial, p. 61-82, out2011 - ISSN: 1676-2584 81 
SWEET, D. Francisca: Indian slave. In: SWEET, D. \& NASH, G. (Org.). Struggle and survival in colonial America. Los Angeles: The University of California Press, 1981. p. 274-291.

TORRES-LONDOÑO, F. La experiencia religiosa jesuita y la crónica misionera de Pará y Maranhão en el siglo XVII. In: MARZAL, M.M., SJ (Org.). Un reino de la frontera: las misiones jesuíticas en la América colonial. Lima: Abya-Ayala/Pontificia Universidad Católica del Perú, 1999. pp. 15-36.

Notas.

${ }^{1}$ Esta pesquisa conta com o apoio do CNPq e da FAPESPA. Uma primeira versão deste trabalho foi apresentada na IX Jornada do HISTEDBR, realizada de 7 a 9 de julho de 2010, na Universidade Federal do Pará.

${ }^{2}$ A esse respeito, ver: ALMEIDA, 2005.

${ }^{3}$ Para um panorama mais amplo da educação na Amazônia colonial, ver: SILVA, 1985.

${ }^{4}$ A respeito do lugar da confissão no mundo moderno, ver: DELUMEAU, 1991.

${ }^{5}$ Para Marques, o aumento da influência política dos jesuítas na Corte abriu as portas da ordem "a todo tipo de perigos de vizinhança". Justamente, esta situação contribuiu para "moldar a imagem pública da Companhia desde o início até o século XVIII" (MARQUES, 1996, p. 227-228).

${ }^{6}$ Sobre as devoções marianas no Maranhão, ver: LEITE, 1943b, p. 242-244.

${ }^{7}$ Há que se lembrar, como aponta o padre Serafim Leite, que a instrução elementar não foi exclusividade dos jesuítas (LEITE, 1943b, p. 271).

${ }^{8}$ Sobre o Regimento das Missões, ver MELLO, 2009.

${ }^{9}$ Diante do debate sobre o curral de gado da Ilha do Marajó do Colégio de Santo Alexandre, o padre Leite afirma que a criação de gado da Companhia de Jesus "revestia aspecto de utilidade pública, e os jesuítas foram durante algum tempo os fornecedores de carne às cidades, tanto do Pará como do Maranhão" (LEITE, 1943b, p. 200).

Recebido em: $\quad$ 04/09/2011

Aprovado em: $\quad$ 10/09/2011 